
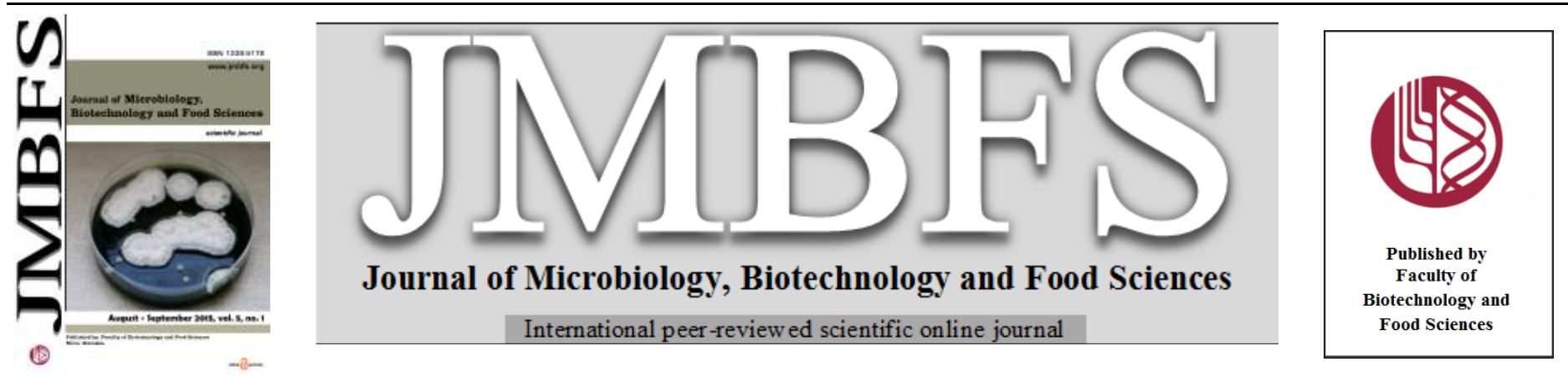

\title{
ANTIOXIDANT EFFICIENCY OF RESVERATROL ON OXIDATIVE STRESS-INDUCED DAMAGE IN BOVINE SPERMATOZOA
}

\author{
Eva Tvrdá*, Anton Kováčik, Eva Tušimová, Norbert Lukáč, Jana Lukáčová, Peter Massányi
}

Address(es): MSc. Eva Tvrdá, PhD.

Slovak University of Agriculture in Nitra, Faculty of Biotechnology and Food Sciences, Department of Animal Physiology, Tr. A. Hlinku 2, 94976 Nitra, +421 37641 4288

*Corresponding author: evina.tvrda@gmail.com

doi: 10.15414/jmbfs.2015.5.1.64-67

ARTICLE INFO

Received 23. 5. 2015

Revised 3. 6. 2015

Accepted 5. 6. 2015

Published 1. 8. 2015

Regular article OPEN $\partial$ ACCESS

\begin{abstract}
Substantial reports suggest that biologically active compounds isolated from natural sources may offer protection to semen against the incidence of free radical producers, improvement of semen quality, prevention of cryodamage and DNA fragmentation, as well as a general promotion of spermatozoa metabolism. This study was therefore designed to assess the impact of resveratrol (RES), a natural polyphenol and phytoalexin with potential antiviral, anti-inflammatory and antioxidant properties on bovine spermatozoa subjected to oxidative stress induced by ferrous ascorbate during a short-term cell culture (6h). Fresh bovine semen samples were centrifuged, the seminal plasma was removed, the sperm pellet was washed out and the resulting cells were diluted in $2.90 \%$ sodium citrate, divided into equal fractions and subjected to treatment based on a specific concentration of RES $(50,25,10,5,0 \mu \mathrm{mol} / \mathrm{L})$ in the presence of an oxidative stress inducer, i.e. ferrous ascorbate (FeAA) containing $150 \mu \mathrm{mol} / \mathrm{L} \mathrm{FeSO} 4$ and $750 \mu \mathrm{mol} / \mathrm{L}$ ascorbic acid. After $6 \mathrm{~h}$, the spermatozoa motility (using the Computer-aided sperm analysis/CASA system) and superoxide production (via the NBT test) were assessed in each sample. Furthermore, the sperm cells were collected, lysed and examined for the activity of superoxide dismutase and catalase, as well as glutathione and malondialdehyde concentrations. The addition of RES into the culture medium was able to significantly $(\mathrm{P}<0.001)$ slow down the deleterious effects of in vitro-associated free radical production. Concentrations of $25-50$ $\mu \mathrm{mol} / \mathrm{L}$ RES were able to significantly $(\mathrm{P}<0.05)$ prevent the decline of spermatozoa physiology, functional activity and antioxidant capacity as a consequence of FeAA-associated oxidative stress development. Above all, this natural substance showed remarkable effects in stabilizing the activities of enzymatic antioxidants. Finally, we may suggest that resveratrol may be a suitable supplement for the in vitro management and preservation of male gametes.
\end{abstract}

Keywords: Resveratrol, ferrous ascorbate, oxidative stress, spermatozoa, bulls

\section{INTRODUCTION}

Spermatozoa are cells particularly sensitive to oxidative stress (OS) development, thus antioxidants represent an additional protective mechanism against possible free radical (FR) sources, directly scavenge FR, reduce cryo-induced OS or block premature sperm maturation (Gharagozloo and Aitken, 2011; Agarwal et al., 2007). With the early observation that semen parameters could be improved using different antioxidant molecules, substantial attention has been devoted to study their impact on male reproduction in health or disease.

Resveratrol (3,5,4'-trihydroxistilbene; RES) is a polyphenol found in a variety of dietary sources including grapes, red wine, berries, pistachios, plums and peanuts. Being a phytoalexin, its synthesis in plants is triggered in response to exogenous stress factors, such as injury, ultraviolet radiation, exposure to ozone and fungal infection (Alarcón de la Rastra and Villegas, 2007).

RES is a potent modulator of the expression and activity of a multitude of antioxidant enzymes (Alarcón de la Rastra and Villegas, 2007). In vivo, RES has been shown to increase the general antioxidant capacity and to decrease lipid peroxidation (LPO) (Miura et al., 2003; Wenzel et al., 2003). Different studies have reported that RES acts as a direct FR scavenger as well as indirectly as a metal-chelation agent preventing the Fenton reaction (Baur and Sinclair, 2010). In vivo and in vitro studies have reported that RES stimulates and protects rabbit and murine spermatocytes and spermatozoa against LPO (Revel et al., 2001; Shin et al., 2008). It has also been shown to reduce apoptosis in germinal cells (Revel $\boldsymbol{e t}$ al., 2001), and to protect them against environmental toxins (Jiang $\boldsymbol{e t}$ al., 2009). At the same time it has been suggested that RES administration enhances spermatogenesis by stimulating the hypothalamic-pituitary-gonadal axis without exhibiting adverse effects (juan $\boldsymbol{e t}$ al., 2005). Moreover RES may trigger penile erection and enhance blood testosterone levels, testicular sperm count and epididymal sperm motility (Shin et al., 2008). This evidence emphasizes on a significant potential of RES in providing a possible protection to male reproduction.

The aim of this study was to assess the in vitro antioxidant activity of RES against oxidative stress induced in bovine spermatozoa by ferrous ascorbate.

\section{MATERIAL AND METHODS}

Bovine ejaculates used for the following experiments were obtained from 25 adult Holstein Friesian breeding bulls (Slovak Biological Services, Nitra, Slovak Republic) on a regular collection schedule using an artificial vagina. The samples had to accomplish the basic criteria given for the corresponding breed. After collection, the samples were stored in the laboratory at room temperature (22$\left.25^{\circ} \mathrm{C}\right)$.

For the in vitro treatment we followed the protocol established by Bansal and Bilaspuri (2008; 2009). Fresh semen was centrifuged $(800 \times \mathrm{g})$ at $25^{\circ} \mathrm{C}$ for 5 min, seminal plasma was removed, the sperm pellet was washed two times with $2.9 \%$ sodium citrate (SC; $\mathrm{pH} 7.4$; Centralchem, Bratislava, Slovak Republic), resuspended in $2.9 \% \mathrm{SC}$ at a ratio of 1:20. One tube (Control) was supplemented with an OS inducer, i.e. ferrous ascorbate (FeAA) comprising $150 \mu \mathrm{mol} / \mathrm{L} \mathrm{FeSO}_{4}$ (ferrous sulfate; $\mathrm{FeSO}_{4} .7 \mathrm{H}_{2} \mathrm{O}$; Sigma-Aldrich, St. Louis, USA) and $750 \mu \mathrm{mol} / \mathrm{L}$ ascorbic acid (Centralchem, Bratislava, Slovak Republic), diluted in $2.9 \%$ SC. The remaining four tubes (experimental portions) were subjected to resveratrol $(5,10,25,50 \mu \mathrm{mol} / \mathrm{L}$ trans-resveratrol; Sigma-Aldrich, St. Louis, USA) treatment in the presence or absence of FeAA. Specific RES concentrations were chosen upon the data obtained from a previous standardization study on bovine spermatozoa (Tvrdá et al., 2015). All sperm suspensions were incubated at $37^{\circ} \mathrm{C}$. At $6 \mathrm{~h}$, spermatozoa motility and intracellular superoxide production were assessed in each sample. Furthermore each sample was centrifuged at $800 \mathrm{x} \mathrm{g}$ at $25^{\circ} \mathrm{C}$ for $10 \mathrm{~min}$. The culture media were removed and the resulting pellet was 
sonicated at $28 \mathrm{kHz}$ for $30 \mathrm{sec}$ on ice using RIPA buffer (Sigma-Aldrich, St. Louis, USA) with protease inhibitor cocktail suitable for mammalian cell and tissue extracts (Sigma-Aldrich, St. Louis, USA). Subsequently the samples were centrifuged at $11828 \mathrm{x} \mathrm{g}, 4^{\circ} \mathrm{C}$ for $15 \mathrm{~min}$ to purify the lysates from residual cell debris. The resulting supernatants involving the intracellular sperm content were stored at $-80^{\circ} \mathrm{C}$ for further assessment of the oxidative profile.

Spermatozoa motility (MOT; percentage of motile spermatozoa; motility >5 $\mu \mathrm{m} / \mathrm{s} ; \%$ ), was assessed with the help of the Computer-aided sperm analysis (CASA) system using the SpermVision ${ }^{\mathrm{TM}}$ program (Minitube, Tiefenbach, Germany) and Olympus BX 51 phase contrast microscope (Olympus, Tokyo, Japan). The samples were placed into the Makler Counting Chamber (depth 10 $\mu \mathrm{m}, 37^{\circ} \mathrm{C}$; Sefi Medical Instruments, Haifa, Israel) and at least 1000 cells were evaluated (Massanyi et al., 2008).

The nitroblue-tetrazolium (NBT) test was used to study the intracellula formation of the superoxide radical, by counting the cells containing blue NBT formazan deposits, which originate due to a reduction of the membrane permeable, water-soluble, yellow-colored, nitroblue tetrazolium chloride $\left(2,2^{\prime}\right.$ bis(4-Nitrophenyl)-5,5'-diphenyl-3,3'-(3,3'-dimethoxy-4,4'diphenylene)

ditetrazolium chloride; Sigma-Aldrich, St. Louis, USA) by the superoxide radica (Tvrdá et al., 2015)

Superoxide dismutase (SOD) activity was analyzed using the Randox RANSOD commercial kit (Randox Laboratories, Crumlin, Great Britain) employing xanthine and xanthine oxidase $(\mathrm{XO})$ to generate superoxide radicals, which will react with 2-(4-iodophenyl)-3-(4-nitrophenol)-5-phenyltetrazolium chloride (I.N.T.) to form a red formazan dye. SOD activity was then measured by the inhibition degree of the reaction at $505 \mathrm{~nm}$ using the Genesys 10 spectrophotometer (Thermo Fisher Scientific Inc., Waltham, USA). The SOD activity is expressed as U/mg protein (Tvrda et al., 2012).

Catalase (CAT) activity was assessed according to Beers and Sizer (1952) by monitoring the decrease of hydrogen peroxide $\left(\mathrm{H}_{2} \mathrm{O}_{2}\right)$ at $240 \mathrm{~nm}$. The calculation was based on the rate of $\mathrm{H}_{2} \mathrm{O}_{2}$ decomposition, proportional to the reduction of the absorbance during $1 \mathrm{~min}$ measured with the Genesys 10 spectrophotometer (Thermo Fisher Scientific Inc., Waltham, USA). The values are expressed as $\mathrm{U} / \mathrm{mg}$ protein.

Reduced glutathione (GSH) was determined by the Ellman method (Ellman, 1957). The sample was treated with DTNB (5,5'-dithiobis-(2-nitrobenzoic acid); Ellman's reagent; Sigma-Aldrich, St. Louis, USA) which interacts with the thiol groups of GSH, cleaving the disulfide bond to give 2-nitro-5-thiobenzoate (NTB ) and creating the $\mathrm{NTB}^{2-}$ dianion in water at neutral and alkaline $\mathrm{pH}$. This ion has a yellow color and was quantified at $412 \mathrm{~nm}$ using the Genesys 10 spectrophotometer (Thermo Fisher Scientific Inc., Waltham, USA). The GSH concentration is expressed as $\mathrm{mg} / \mathrm{g}$ protein

Lipid peroxidation (LPO) expressed through malondialdehyde (MDA) concentration was assessed with the help of the TBARS assay, modified for a 96well plate and ELISA reader. Each sample was treated with 5\% sodium dodecyl sulfate, and subjected to $0.53 \%$ tiobarbituric acid (TBA; Sigma-Aldrich, St Louis, USA) dissolved in $20 \%$ acetic acid adjusted with $\mathrm{NaOH}$ (Centralchem, Bratislava, Slovak Republic) to $\mathrm{pH} 3.5$, and subsequently boiled at $90-100{ }^{\circ} \mathrm{C}$ for $1 \mathrm{~h}$. After boiling, the samples were placed on ice for $10 \mathrm{~min}$ and centrifuged at $1750 \times \mathrm{g}$ for $10 \mathrm{~min}$. Supernatant was used to measure the end-product resulting from the reaction of MDA and TBA under high temperature and acidic conditions at 530-540 $\mathrm{nm}$ with the help of the Multiskan FC microplate photometer (Thermo Fisher Scientific Inc., Waltham, USA) (Tvrdá et al., 2013). Protein concentration was assessed using the DiaSys Total Protein (DiaSys, Holzheim, Germany) commercial kit and the semi-automated clinical chemistry photometric analyzer Microlab 300 (Merck $^{\circledR}$, Darmstadt, Germany). The measurement is based on the Biuret method, according to which copper sulfate react with proteins to form a violet blue color complex in alkaline solution, and the intensity of the color is directly proportional to the protein concentration when measured at $540 \mathrm{~nm}$ (Tvrdá et al., 2011).

Statistical analysis was carried out using the GraphPad Prism program (version 3.02 for Windows; GraphPad Software, La Jolla California USA, www.graphpad.com). Descriptive statistical characteristics (mean, standard error) were evaluated at first. One-way ANOVA was used for specific statistical evaluations. Dunnett's test was used as a follow up test to ANOVA, based on a comparison of every mean to a control mean, and computing a confidence interval for the difference between the two means. The level of significance was set at ${ }^{* * *}(\mathrm{P}<0.001) ;{ }^{* *}(\mathrm{P}<0.01) ;{ }^{*}(\mathrm{P}<0.05)$.

\section{RESULTS AND DISCUSSION}

Supplementation of RES led to an overall dose-dependent preservation of the spermatozoa vitality and an enhancement of the antioxidant balance. RES administration to the FeAA groups has led to a significant improvement of the spermatozoa motility $(\mathrm{P}<0.001$ in relation to $10-50 \mu \mathrm{mol} / \mathrm{L}$ RES and $\mathrm{P}<0.05$ with respect to $5 \mu \mathrm{mol} / \mathrm{L}$ RES) when compared to the Control (Table 1).

Table 1 Spermatozoa motility (\%) and antioxidant characteristics affected by four doses of resveratrol (RES), treated with ferrous ascorbate (FeAA). (Mean \pm SEM; $n=25$ )

\begin{tabular}{|c|c|c|c|c|c|}
\hline Parameter & Ctrl & $\mathbf{A}$ & B & $\mathbf{C}$ & D \\
\hline MOT [\%] & $11.22 \pm 1.08$ & $34.59 \pm 2.53^{* * *}$ & $30.68 \pm 2.55^{\text {*** }}$ & $25.05 \pm 2.24^{* * *}$ & $23.99 \pm 2.01^{* *}$ \\
\hline SOD [U/mg prot] & $0.08 \pm 0.02$ & $0.18 \pm 0.03^{* * *}$ & $0.15 \pm 0.04^{* *}$ & $0.13 \pm 0.01^{* *}$ & $0.12 \pm 0.02^{* *}$ \\
\hline CAT [U/mg prot] & $3.85 \pm 0.50^{*}$ & $8.68 \pm 1.07^{* *}$ & $8.10 \pm 0.73^{* *}$ & $7.25 \pm 1.74^{*}$ & $7.00 \pm 1.14$ \\
\hline GSH [mg/g prot] & $5.00 \pm 0.73$ & $8.55 \pm 1.71^{*}$ & $8.44 \pm 1.41^{*}$ & $8.00 \pm 1.41^{*}$ & $7.45 \pm 1.22$ \\
\hline MDA $[\mu \mathrm{mol} / \mathrm{g}$ prot $]$ & $10.55 \pm 1.45$ & $4.03 \pm 0.18^{* * * *}$ & $4.89 \pm 0.45^{* * *}$ & $4.87 \pm 0.75^{* * *}$ & $4.99 \pm 0.94^{* * *}$ \\
\hline
\end{tabular}

The ROS-scavenging activity of RES was confirmed by the NBT test (Figure 1) according to which, RES was able to significantly reduce the superoxide production $(\mathrm{P}<0.001$ with respect to $50 \mu \mathrm{mol} / \mathrm{L}$ RES and $\mathrm{P}<0.01$ in case of $5-25$ $\mu \mathrm{mol} / \mathrm{L}$ RES).

Examination of the effects of RES on the oxidative balance of spermatozoa revealed that higher concentrations of RES were able to at least partially restore the antioxidant activities of SOD ( $\mathrm{P}<0.001$ with respect to $50 \mu \mathrm{mol} / \mathrm{L}$ RES and $\mathrm{P}<0.01$ in case of $5-25 \mu \mathrm{mol} / \mathrm{L}$ RES) and CAT $(\mathrm{P}<0.01$ with respect to $25-50$ $\mu \mathrm{mol} / \mathrm{L}$ RES and $\mathrm{P}<0.05$ in relation to $10 \mu \mathrm{mol} / \mathrm{L}$ RES). Furthermore, RES concentrations from 5 to $50 \mu \mathrm{mol} / \mathrm{L}$ caused a significant increase of the GSH concentration ( $\mathrm{P}<0.05$ with respect to $10-50 \mu \mathrm{mol} / \mathrm{L}$ RES) when compared to the Control, along with a significant decrease of the MDA $(\mathrm{P}<0.001)$ content.

Currently, substantial evidence indicates that RES may be beneficial to different aspects of human and animal health. Interest in this substance has risen since the discovery of a variety of biological properties, such as antioxidant, immunomodulative, cardioprotective and anti-inflammatory characteristics. [14] Nevertheless, different in vitro studies have shown that RES exhibits a dosedependent activity on the cell, with a notable dichotomy: low doses improve cell survival, while high doses have the potential to promote apoptosis. [15] RES supplementation in this study resulted in a stabilization of spermatozoa motility over the in vitro cultivation period. Collodel et al. [47] studied the effects or RES on the motility properties of swim-up spermatozoa. At $100 \mu \mathrm{M}$ RES, the motility was completely missing in all samples, while progressive motility reached its maximum at 6 and $15 \mu \mathrm{M}$ RES. In a different study [25] 100 and 200 $\mu \mathrm{M} / \mathrm{L}$ RES did not exhibit lethal effects on the spermatozoa vitality, however its presence suppressed all sperm activity characteristics.

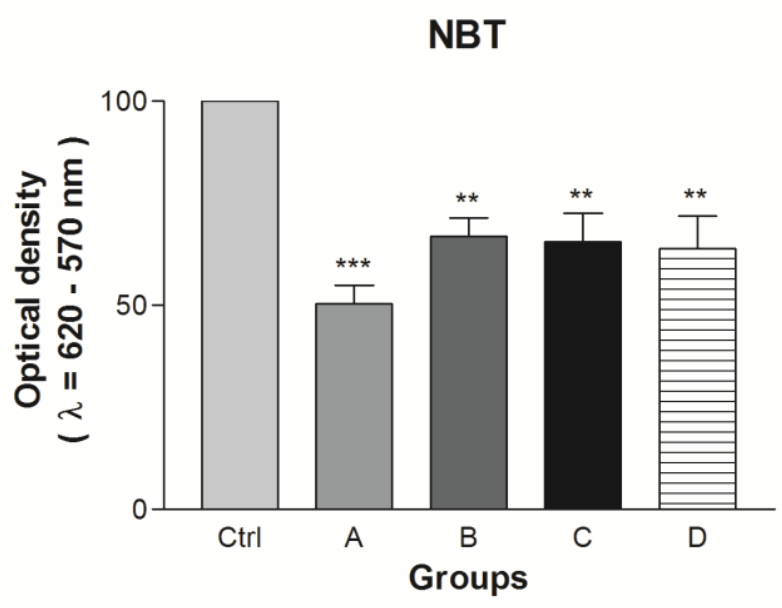

Figure 1 Intracellular superoxide production of bovine spermatozoa affected by four doses of resveratrol (RES), co-treated with ferrous ascorbate (FeAA). Each bar represents mean $( \pm$ SEM) optical density as the percentage of the Control, which was set to $100 \%$ and the data are expressed as a $\%$ of the Control value. The data were obtained from five independent experiments. The level of significance was set at ${ }^{*}-\mathrm{P}<0.05 ;{ }^{* *}-\mathrm{P}<0.01 ;^{* * *}-\mathrm{P}<0.001 \mathrm{~A}-50 \mu \mathrm{mol} / \mathrm{L}$ RES, $\mathrm{B}-25 \mu \mathrm{mol} / \mathrm{L}$ RES; C - $10 \mu \mathrm{mol} / \mathrm{L} \mathrm{RES}$; D - $5 \mu \mathrm{mol} / \mathrm{L}$ RES. 
RES concentrations ranged from 5 to $50 \mu \mathrm{mol} / \mathrm{L}$, which are ought to exhibit a significant motility preservation (Collodel et al., 2010; Mojica-Villegas et al., 2014; Tvrdá et al., 2015). The CASA records are in agreement with MojicaVillegas $\boldsymbol{e}$ t al. (2014) reporting that pretreatment with $15 \mu \mathrm{g} / \mathrm{mL}$ RES $15 \mathrm{~min}$ prior to incubation with FeAA resulted in an 8.0 fold increase of mouse spermatozoa motility and a 2.0 fold increase in their viability. On the other hand, sperm motility diminished in samples cryopreserved with RES when compared to the control in the studies by Pasqualotto et al. (2006) and Garcez et al. (2010). Furthermore Silva et al. (2012) reported that RES supplementation before cryopreservation did not significantly alter motility, vigor, acrosome integrity, or plasma membrane integrity. Meanwhile, Sarlós et al. (2002) reported a higher motility and acrosome integrity of ram spermatozoa supplemented with RES after storage at $5^{\circ} \mathrm{C}$ for 6 days. Similar results were obtained in swim-up human spermatozoa where low RES doses led to a higher progressive motility (Collodel et al., 2010).

The present study shows that RES prevents the generation of intracellular superoxide radical induced by FeAA in spermatozoa as seen in the NBT test, suggesting the antioxidant potential of RES. Similar results were recorded in our previous study (Tvrdá et al., 2015), in which 10 and $50 \mu \mathrm{mol} / \mathrm{L}$ RES had an instant and significant protective effect on the intracellular superoxide production in bovine sperm. The mitochondrial system is the primary producer of intracellular FR (Turrens, 2003), with the respiratory chain acting in autoxidation processes, while polyphenols including RES play important roles in the absorption and neutralization of FR, because of their oxido-reduction properties (Alarcón de la Rastra and Villegas, 2007).

A notable RES property is its antioxidant potential, as it is able to reach peroxidized rigid membranes and increase the membrane fluidity in order to interact more efficiently with FR in the altered lipid bilayer (Alarcón de la Rastra and Villegas, 2007). Hence, RES may exhibit protective effects agains LPO in cell membranes as shown by Frèmont (2000).

RES-related stimulation of antioxidant mechanisms is further evidenced by the activities of SOD and CAT in spermatozoa. We found that RES may prevent the decrease of SOD and CAT activity resulting from exposure to FeAA. MojicaVillegas et al. (2014) did not find any significant difference in the SOD activity following RES pretreatment, while according to Pasqualotto et al. (2006), SOD levels remained unchanged when spermatozoa were cryopreserved with RES. On the other hand, CAT levels increased in spermatozoa cryopreserved with three different RES concentrations. Ourique et al. (2013) demonstrated that treatment with RES prevented the reduction in the testicular CAT activity of T3-induced hyperthyroid rats, supporting its role in FR inactivation and modulation of antioxidant defense systems.

GSH content was measured to study the RES impact on non-enzymatic antioxidants in the male germ cell. As opposed to Ourique et al. (2013) our study shows that the GSH levels differed significantly among all experimenta groups. Mojica-Villegas et al. (2014) observed a decrease of GSH as a response to FeAA administration followed by restorative effects of RES on this peptide. Also, Olas et al. (2004) propose that RES may at least partially protect the -SH groups from oxidation.

Polyphenols are ought to be easily incorporated into the membrane lipid bilayer, inhibiting the formation of lipid radicals, keeping the membrane integrity of the cell (Frèmont, 2000; López-Vélez et al., 2003). Thus, TBARS analysis was carried out to confirm this hypothesis. Our results indicate that RES was effective in preventing LPO induced by FeAA, being consistent with the reports by Mojica-Villegas et al. (2014) promoting OS via FeAA in murine spermatozoa, as well as by Collodel $\boldsymbol{e t}$ al., (2010) via tert-butyl hydroperoxide in human sperm, and hypothesizing that the protective effects of RES against LPO might be attributed to a hydrogen electron donation from its hydroxyl groups (LópezVélez et al., 2003).

\section{CONCLUSION}

In conclusion, this study provides evidence that resveratrol is able to prevent the decline of spermatozoa vitality and antioxidant capacity as a consequence of FeAA-associated oxidative stress development. Resveratrol concentrations of 25 $50 \mu \mathrm{mol} / \mathrm{L}$ were notably effective in protecting bovine spermatozoa through protection against lipid peroxidation as well as stabilization of enzymatic antioxidants. Hence, resveratrol administration may be a suitable strategy to to prevent oxidative damage of the sperm structural integrity and functional activity.

Acknowledgments: This work was co-funded by the European Community under the Project no. 26220220180: Building Research Centre „AgroBioTech" and by the Scientific Grant Agency of the Ministry of Education of the Slovak Republic and of the Slovak Academy of Sciences VEGA Project no. 1/0857/14.

\section{REFERENCES}

AGARWAL, A., PRABAKARAN, S.A., SIKKA S.C. 2007. Clinical relevance of oxidative stress in patients with male factor infertility: evidence-based analysis. AUA Update Series, 26, 1-12. http://dx.doi.org/10.1111/j.16000897.2007.00559.x.
ALARCÓN DE LA RASTRA, C., VILLEGAS, I. 2007. Resveratrol as an antioxidant and pro-oxidant agent: mechanisms and clinical implications. Biochemical Society $\quad$ Transactions, $\quad 35(5), \quad 1156-1160$ http://dx.doi.org/10.1042/BST0351156.

BANSAL, A.K., BILASPURI, G.S. 2008. Effect of ferrous sulphate and ascorbic acid on motility, viability and lipid peroxidation of crossbred cattle bull spermatozoa. Animal, 2(1)

http://dx.doi.org/0.1017/S1751731107000961.

BANSAL, A.K., BILASPURI, G.S. 2009. Antioxidant effect of vitamin E on motility, viability and lipid peroxidation of cattle spermatozoa under oxidative stress. Animal Science Papers and Reports, 27(1), 5-14.

BAUR, J.A., SINCLAIR, D.A. 2010. Therapeutic potential of resveratrol: the in vivo evidence. Nature Reviews Drug Discovery, 6, 493-506. http://dx.doi.org/10.1038/nrd2060.

BEERS, R.F. JR., SIZER, I.W. 1952. A spectrophotometric method for measuring the breakdown of hydrogen peroxide by catalase. The Journal of Biological Chemistry, 195(1), 133-140.

COLLODEL G., FEDERICO M.G., GEMINIANI M., MARTINI S., BONECHI C., ROSSI C., FIGURA N., MORETTI E. 2010. Effect of trans-resveratrol on induced oxidative stress in human sperm and in rat germinal cells. Reproductive Toxicology, 31(2), 239-246. http://dx.doi.org/10.1016/j.reprotox.2010.11.010.

ELLMAN, G.L. 1957. Tissue sulfhydryl groups. Archives of Biochemistry and Biophysics, 82(1), 70-77.

GARCEZ, M.E., BRANCO, C.D., LARA, L.V., PASQUALOTTO, F.F. SALVADOR, M. 2010. Effects of resveratrol supplementation on cryopreservation medium of human semen. Fertility and Sterility, 94(6), 2118 2121. http://dx.doi.org/10.1016/j.fertnstert.2010.01.058.

GHARAGOZLOO, P., AITKEN, R.J. 2011. The role of sperm oxidative stress in male infertility and the significance of oral antioxidant therapy. Human Reproduction, 26(7), 1628-1640. http://dx.doi.org/10.1093/humrep/der132.

FRÈMONT, L. 2000. Biological effects of resveratrol. Life Sciences, 66, 663 673. http://dx.doi.org/10.1089/152308601317203567.

JIANG, Y., PENH, T., LUO, Y., LI, M., LIN, Y. 2008. Resveratrol reestablishes spermatogenesis after testicular injury in rats caused by 2,5-hexanedione Chinese Medical Journal, 121(13), 1204-1209.

JUAN, E., GONZÁlES-PONS, E., MUNUERA, T., BALLESTER, J. RODRÍGUEZ-GIL, J. E., PLANAS, J. M. 2005. Trans-resveratrol, a natural antioxidant from grapes, increases sperm output in healthy rats. Journal of Nutrition, 135, 757-760

LÓPEZ-VÉLEZ, M., MARTÍNEZ-MARTÍNEZ, F., DEL VALLE-RIBES, C. 2003. The study of phenolic compounds as natural antioxidants in wine. Critical Reviews in Food Science and Nutrition, 43(3), 233-244. http://dx.doi.org/10.1080/10408690390826509.

MASSANYI, P., CHRENEK, N., LUKÁČ, N., MAKAREVICH, A.V., OSTRO, A., ŽIVCAK, J., BULLA, J. 2008. Comparison of different evaluation chambers for analysis of rabbit spermatozoa motility using CASA system. Slovak Journal of Animal Science, 41, 2008, 60-66.

MIURA, D., MIURA, Y., YAGASAKI, K. 2003. Hypolipidemic action of dietary resveratrol, a phytoalexin in grapes and red wine, in hepatoma-bearing rats. Life Sciences, 73, 1393-1400. http://dx.doi.org/10.1016/S0024 3205(03)00469-7.

\section{MOJICA-VILLEGAS, M.A., IZQUIERDO-VEGA, J.A., CHAMORRO}

CEVALLOS, G., SANCHEZ-GUITERREZ, M. 2014. Protective effect of resveratrol on biomarkers of oxidative stress induced by iron/ascorbate in mouse spermatozoa. Nutrients, 6, 489-503. http://dx.doi.org/10.3390/nu6020489.

OLAS, B., NOWAK, P., WACHOWICZ, B. 2004. Resveratrol protects against peroxynitrite-induced thiol oxidation in blood platelets. Cellular \& Molecular Biology Letters, 9(4A), 577-587.

OURIQUE, G.M., FINAMOR, I.A., SACCOL, E.M., RIFFEL, A.P., PÊS, T.S. GUTIERREZ, K., GONÇALVES, P.B., BALDISSEROTTO, B., PAVANATO, M.A., BARRETO, K.P. 2013. Resveratrol improves sperm motility, prevents lipid peroxidation and enhances antioxidant defences in the testes of hyperthyroid
rats.
Reproductive
Toxicology
37
31-39.

http://dx.doi.org/10.1016/j.reprotox.2013.01.006

PASQUALOTTO, F.F., GARCEZ, M., BORGES, E., GUPTA, S., SALVADOR, M., AGARWAL, A. 2006. Lipid peroxidation, superoxide dismutase, catalase levels and sperm motility: protective role of vitamin $\mathrm{C}$ and resveratrol prior to sperm cryopreservation. Fertility and Sterility, 86, S446.

REVEL, A., RAANANI, H., YOUNGLAI, E., XU, J., HAN, R., SAVOURET, J.F., CASPER, R.F. 2001. Resveratrol, a natural aryl hydrocarbon receptor antagonist, protects sperm from DNA damage and apoptosis caused by benzo(a)pyrene. Reproductive Toxicology, 15(5), 479-486.

SARLÓS, P., MOLNÁR, A., KÓKAI, M., GÁBOR, G., RÁTKY, J. 2002. Comparative evaluation of the effect of antioxidants in the conservation of ram semen. Acta Veterinaria Hungarica, 50, 235-245.

SHIN S., JEON J.H., PARK D., JANG M.J., CHOI J.H., CHOI B.H. 2008 Trans-resveratrol relaxes the corpus cavernosum ex vivo and enhances testosterone levels and sperm quality in vivo. Archives of Pharmacal Research, 31, 83-87. http://dx.doi.org/10.1007/s12272-008-1124-7. 
SILVA, E.C., CAJUEIRO, J.F., SILVA, S.V., SOARES, P.C., GUERRA, M.M. 2012. Effect of antioxidants resveratrol and quercetin on in vitro evaluation of frozen ram sperm. Theriogenology, 77, 1722-1726. http://dx.doi.org/10.1016/j.theriogenology.2011.11.023.

TURRENS, J.F. 2003. Mitochondrial formation of reactive oxygen species. The Journal of Physiology, 552, 335-344.

TVRDA, E., KNAZICKA, Z., LUKAC, N. 2012. Selected heavy metals versus antioxidant parameters in bull seminal plasma - a comparative study. Journal of Environmental Science and Health Part A, 47(9), 1261-1266. http://dx.doi.org/10.1080/10934529.2012.672117.

TVRDÁ, E., KŇAŽICKÁ, Z., MASSÁNYI, P., LUKÁČ, N. 2011. Relationships between levels of nitrogen compounds with antioxidant properties and semen quality in bulls. Contemporary Agriculture, 60(3-4), 244-252.

TVRDÁ, E., LUKÁČ, N., LUKẢČOVÁ, J., HASHIM F., MASSÁNYI, P. 2015. In vitro supplementation of resveratrol to bovine spermatozoa: effects on motility, viability and superoxide production. Journal of Microbiology, Biotechnology and Food Sciences, 4(4), 336-341. http://dx.doi.org/10.15414/jmbfs.2015.4.4.336-341

TVRDÁ, E., LUKÁČ, N., LUKÁČOVÁ, J., KŇǍŽICKÁ, Z., MASSÁNYI, P. 2013. Stimulating and protective effects of vitamin $E$ on bovine spermatozoa Journal of Microbiology, Biotechnology and Food Sciences, 2(1), 1386-1395.

TVRDÁ, E., KŇAŽICKÁ, Z., LUKÁČOVÁ, J., SCHNEIDGENOVÁ, M., GOC, Z., GREŃ, A., SZABÓ, C., MASSÁNYI, P., LUKÁČ, N. 2013. The impact of lead and cadmium on selected motility, prooxidant and antioxidant parameters of bovine seminal plasma and spermatozoa. Journal of Environmental Science and Health Part A, 48(10), 1292-1300. http://dx.doi.org/10.1080/10934529.2013.777243.

WENZEL, E., SOLDO, T., ERBERSDOBLER, H., SOMOZA, V. 2005. Bioactivity and metabolism of trans-resveratrol orally administered to Wistar rats. Molecular Nutrition \& Food Research, 49, 482-494. http://dx.doi.org/10.1002/mnfr.2005. 